\title{
Optimization of the construction organization's work plans by loading production units
}

\author{
Pavel Oleinik ${ }^{1}$ and Alexey Yurgaytis ${ }^{1, *}$ \\ ${ }^{1}$ Moscow State University of Civil Engineering, 129337, 26, Yaroslavskoye Shosse, Moscow, Russia
}

\begin{abstract}
In the article, the authors consider the problems of complex algorithmization and systematization of approaches to optimizing the work plans of construction organizations using various modern tools, including, for example, evolutionary algorithms of "conscious" enumeration of options for solving a target function from an array of possible constraints for a given nomenclature. Various standard schemes for modeling the processes of distribution of labor resources between the objects of the production program are given. As the results of the study, the authors formulate the conceptual algorithm underlying the written software package for the operational harmonization of the production program (work plans) in accordance with the loading of production units, released labor resources and other conditions stipulated by the model.
\end{abstract}

\section{Introduction}

The modern formulation of the optimization problem allows us to consider the directions of introducing some popular mathematical methods into algorithms for solving the engineering problem of forming work plans when developing a production program for a construction organization. Advantage of mathematical methods is dictated primarily by the multifaceted and complex processes of optimizing and harmonizing work plans in the conditions of a modern market economy, when the work plans of the production program and scheduling as a whole must timely respond to fluctuations in the building system with its set of destabilizing factors, including - in the absence of a clear system of current, operational and strategic planning, organizational structure of management organization and the spontaneous addition of work during the reporting year for which such program is being formed.

To realize the possibility of operational and current management of complex processes, such as investment and construction projects, military-industrial complex projects, in the second half of the 1950s in the United States of America the first network planning and control algorithms based on discrete models were developed (table 1).

\footnotetext{
*Corresponding author: aljurgaitis@gmail.com
} 
Table 1. Network Planning Method Groups

\begin{tabular}{|c|c|l|}
\hline № & Network Planning Method Groups & \multicolumn{1}{c|}{ Method Examples } \\
\hline 1 & Deterministic & Critical path method \\
\hline 2 & Probabilistic & $\begin{array}{l}\text { Monte Carlo Method, PERT - } \\
\text { Evaluation and Review of Plans }\end{array}$ \\
\hline 3 & Alternative & $\begin{array}{l}\text { GERT - graphical assessment and } \\
\text { analysis }\end{array}$ \\
\hline
\end{tabular}

The network model itself, as can be seen from Table 2, is a discrete mathematical structure (object) - a graph, the corresponding mathematical rules, approaches and algorithms are obviously applicable to the modeling and calculation of such graphs. In this case, when studying such mathematical operations, it is logical to turn to discrete mathematics sections and identify similar problems in their formulation that can be adapted and applied to solve engineering problems of the building complex.

Table 2. Principle comparison of graphical modeling of a network and graph.

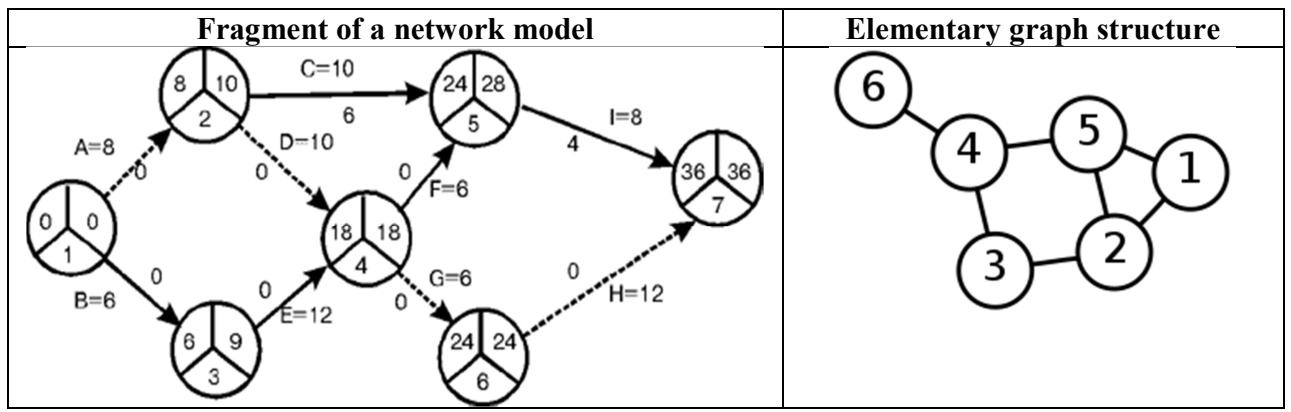

To solve such combinatorial optimization problems, evolutionary algorithms developed in the USA as a branch of the development of artificial intelligence in 1957 can also be applied. The adoption of managerial decisions and the development of the optimal value of the function in solving such problems was based on the analysis of the functioning of biological systems, which, in the process of evolution, heuristically achieve the optimization of various life processes. As examples of the prospective development of such algorithms, a number of particular statements appear, inspired by the study of the swarm behavior of some species of insects (ants and wasps) [1-5]. Thus, many combinatorial problems solved primarily by enumeration received a powerful mathematical tool for processing a large number of combinations of elements of systems. If we turn to the practice of implementing such methods in solving the tasks of scheduling and resource provision, which specialists in the field of construction organization regularly encounter both at the current planning stage when forming the annual (two-year) production program of a construction organization, and at the operational stage management of construction production in the preparation of weekly and daily plans, organizational and technological design, scheduling plans, etc., - we can obtain promising approach imposing the adjoint on current engineering problems. Thus, the classical task of the distribution of labor resources (Fig. 1), which arises especially sharply when considering just a number of objects combined in a certain program, can be solved using the given genetic algorithms. 


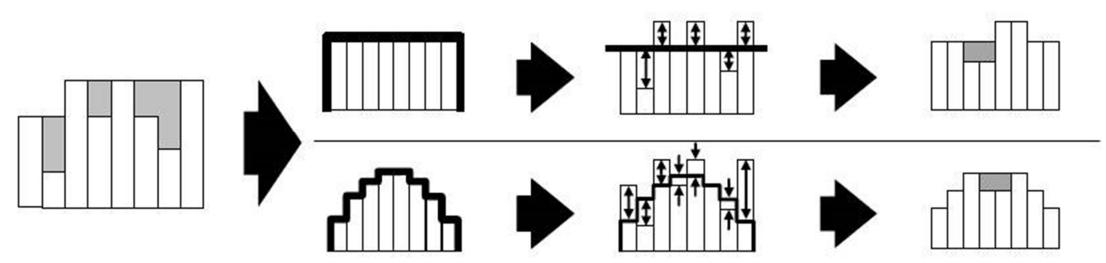

Fig. 1. Standard problems of resource allocation by inefficient forms of demand plots.

\section{Materials and Methods}

Initially, the priority of the objects of the production program by the timing of implementation in accordance with the requirements of the construction contract concluded is proposed to be determined in accordance with the following principle (see Figure 2) : the objects of the production program (portfolio of the construction organization) are conventionally divided into four principal types (see table 3), and objects whose launch is planned in the current reporting period (Type 1 and Type 2) will be considered critical. Accordingly, in the subsequent reporting period, the transition of noncritical objects to the category of critical is envisaged $[6,7,8,9,10,11]$.

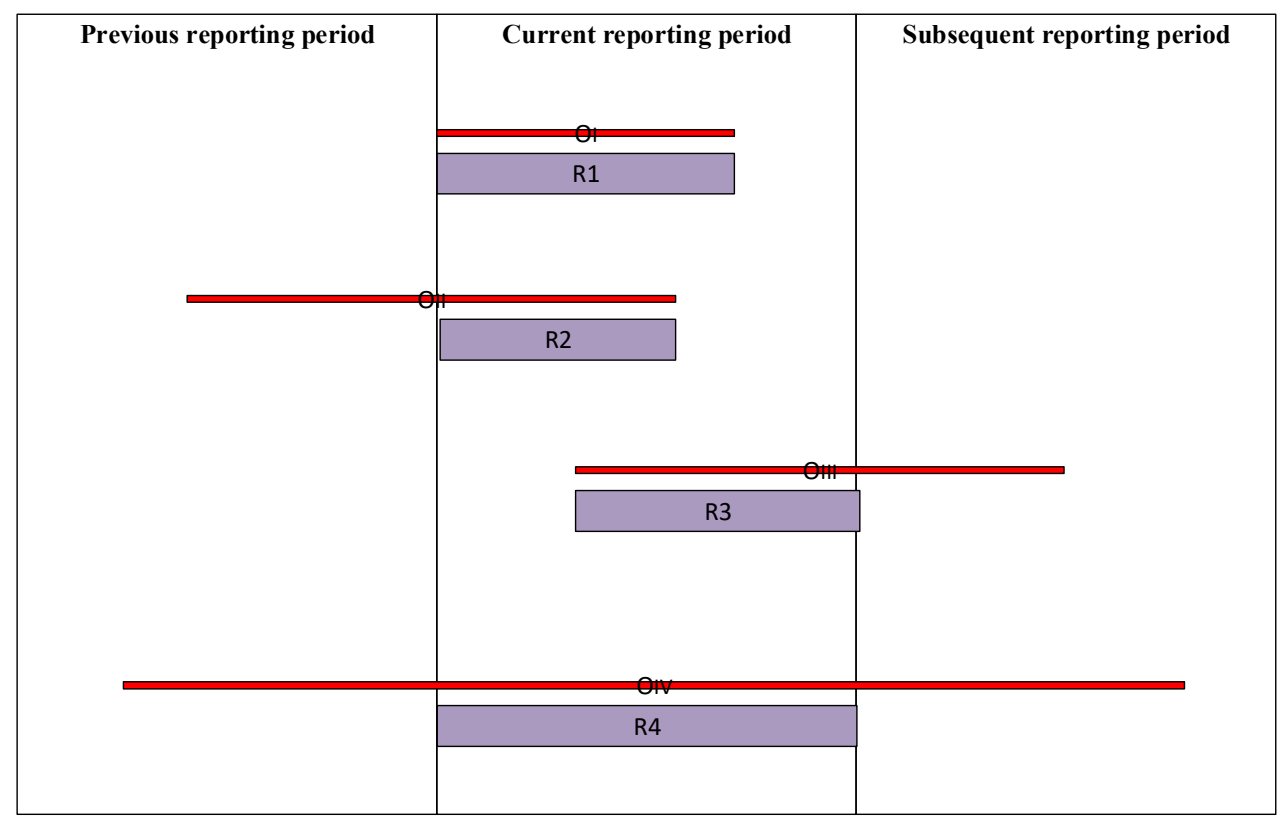

$\mathrm{R}$ - Initial resource of the construction organization

Fig. 2. The basis of modeling the production program (work plan in its composition) taking into account the priority of the implementation of the facilities (their criticality in accordance with the terms of the work from the concluded construction contracts).

List of variables and symbols: 
$\left(O_{n}^{m}\right)$ - The object of the production program of the construction organization under the serial number in the region;

$O_{I} \ldots O_{I V}$ about the object of the production program of the construction organization for the criticality of implementation in accordance with the terms of implementation of type I IV, respectively;

$R 1 \ldots R 4$ - the required labor resource for objects of the corresponding types according to the degree of criticality;

$R-$ a similar resource of the construction organization, providing planned (predicted) capacity;

- the object requires special control of the saturation front work of labor resources (the highest or high priority, respectively for critical objects I -th and II -th birth);

- a non-critical object expects a transition to the category of critical (in the next reporting period), is supplied with a resource according to the residual principle;

- conditional designation deadline monolithic works in accordance with the provisions of the building contract.

Table 3. Characteristics of the objects according to the degree of criticality of their implementation as part of the production program, depending on the approved contractual terms for the construction and installation works.

\begin{tabular}{|l|c|c|c|c|}
\hline No & $\begin{array}{c}\text { Type in } \\
\text { accordance } \\
\text { with the } \\
\text { scheme }\end{array}$ & $\begin{array}{c}\text { Additional } \\
\text { designation for } \\
\text { morphological } \\
\text { analysis }\end{array}$ & Name & Description \\
\hline 1. & $\begin{array}{c}\text { First Type } \\
O_{I} \ldots O_{I V}\end{array}$ & $A$ & Short launcher & $\begin{array}{l}\text { An object that begins and } \\
\text { ends in the current } \\
\text { reporting period. }\end{array}$ \\
\hline 2. & $\begin{array}{c}\text { Second Type- } \\
O_{I I}\end{array}$ & $B$ & Long launcher & $\begin{array}{l}\text { An object that began in the } \\
\text { past but ends in the current } \\
\text { reporting period. }\end{array}$ \\
\hline 3. & $\begin{array}{c}\text { Third Type- } \\
O_{I I}\end{array}$ & Landing Object & $\begin{array}{l}\text { Objects, construction of } \\
\text { which begins in the current } \\
\text { reporting period, and } \\
\text { commissioning is carried } \\
\text { out in the subsequent } \\
\text { reporting period }\end{array}$ \\
\hline 4. & $\begin{array}{c}\text { Fourth Type- } \\
O_{I V}\end{array}$ & Transitional (through) & $\begin{array}{l}\text { Object, the beginning and } \\
\text { end of work on which are } \\
\text { outside the current } \\
\text { reporting period }\end{array}$ \\
\hline
\end{tabular}

At the same time, the construction practice illustrates the insufficiency of the approach in determining the priority in the allocation of resource flows by objects, based solely on the analysis of contractual deadlines for the work and their comparison with the planning periods of the current planning (annual program, two-year program). In fact, the object, the commissioning of which is planned in the current reporting period, under certain conditions also has the opportunity to fall into the category of non-critical (the front of work is not open, there is no funding, there is a delay in the development and delivery of working drawings, etc.), that is within a certain period of time, the priority of this object in the appointment of the production units is falling, despite the tight production deadlines of works in accordance with the contract. 
The priority of consideration of the objects of the production program of the construction organization when assigning a labor resource, and in this case should be established as a result of assigning to each object a certain cumulative category of criticality for their implementation - an integral gender and criticality, which is determined by analyzing and summing up the array of properties of the object, expressed through certain morphological characters (table 4). For further morphological features, we will take the properties of a building object obtained as a result of the analysis of scientific and technical literature and the practice of erecting objects from monolithic reinforced concrete.

Table 4. Components of the integral kind of criticality of the object of the production program.

\begin{tabular}{|c|c|c|c|c|c|}
\hline № & $\begin{array}{l}\text { The group } \\
\text { of } \\
\text { properties } \\
\text { of the } \\
\text { object of } \\
\text { the } \\
\text { production } \\
\text { program }\end{array}$ & $\begin{array}{c}\text { Designation } \\
\text { of a group of } \\
\text { properties } \\
\text { when } \\
\text { determining } \\
\text { the integral } \\
\text { kind of } \\
\text { criticality }\end{array}$ & $\begin{array}{l}\text { Component } \\
\text { groups in } \\
\text { determining } \\
\text { the integral kind } \\
\text { of criticality }\end{array}$ & $\begin{array}{l}\text { The designation of the } \\
\text { components of the } \\
\text { group in } \\
\text { determining the integr } \\
\text { al kind of criticality, m }\end{array}$ & $\begin{array}{c}\text { The } \\
\text { weighting } \\
\text { factor for } \\
\text { determining } \\
\text { the } \\
\text { integral type } \\
\text { of } \\
\text { criticality, } \\
k_{m 1}, k_{m 2}, \\
\text { [ dimensionl } \\
\text { ess ] }\end{array}$ \\
\hline 1. & \multirow{4}{*}{$\begin{array}{l}\text { The main } \\
\text { morphologi } \\
\text { cal sign } \\
\text { (property) } \\
\text { is } \\
\text { the criticalit } \\
\text { y of the } \\
\text { object by } \\
\text { the timing } \\
\text { of } \\
\text { implementa } \\
\text { tion }\end{array}$} & \multirow[b]{4}{*}{$G r p_{1}$} & Short launcher & $A$ & 1 \\
\hline 2. & & & Long launcher & $B$ & 1 \\
\hline 3. & & & Landing Object & $C$ & 1 \\
\hline 4. & & & $\begin{array}{l}\text { Transitional (throu } \\
\text { gh) }\end{array}$ & $D$ & 1 \\
\hline 5. & \multirow{6}{*}{$\begin{array}{l}\text { Properties } \\
\text { of the } \\
\text { object, } \\
\text { increasing } \\
\text { the } \\
\text { criticality of } \\
\text { the main } \\
\text { morphologi } \\
\text { cal trait }\end{array}$} & \multirow{6}{*}{$\operatorname{Grp}_{2}$} & Object Status & \multirow{6}{*}{$A^{\prime}$} & 1 \\
\hline 6. & & & $\begin{array}{l}\text { Construction } \\
\text { contract }\end{array}$ & & 1 \\
\hline 7. & & & $\begin{array}{c}\text { Advance under } \\
\text { construction } \\
\text { contract / Monthly } \\
\text { payment }\end{array}$ & & 1 \\
\hline 8. & & & $\begin{array}{l}\text { Initial data } \\
\text { (issuance of } \\
\text { working } \\
\text { documentation for } \\
\text { production in the } \\
\text { prescribed manner; } \\
\text { geodetic alignment } \\
\text { base, etc.) }\end{array}$ & & 2 \\
\hline 9. & & & $\begin{array}{c}\text { Transfer of the } \\
\text { construction site } \\
\text { according to the act }\end{array}$ & & 1 \\
\hline 10. & & & $\begin{array}{c}\text { Preparatory work } \\
\text { (arrangement of } \\
\text { domestic premises }\end{array}$ & & 1 \\
\hline
\end{tabular}




\begin{tabular}{|c|c|c|c|c|c|}
\hline & & & $\begin{array}{c}\text { and } \\
\text { workplaces, procur } \\
\text { ement processes) }\end{array}$ & & \\
\hline 11. & & & $\begin{array}{l}\text { Opening of the } \\
\text { front of works for } \\
\text { the execution of } \\
\text { monolithic works }\end{array}$ & & 5 \\
\hline 12. & & & Source of financing & & 1 \\
\hline 13. & & & $\begin{array}{l}\text { Additional custom } \\
\text { criterion }\end{array}$ & & 1 \\
\hline 14. & & & Other (optional) & & 1 \\
\hline 15. & \multirow{10}{*}{$\begin{array}{l}\text { Object } \\
\text { properties } \\
\text { that lower } \\
\text { the } \\
\text { criticality of } \\
\text { the main } \\
\text { morphologi } \\
\text { cal trait }\end{array}$} & \multirow{10}{*}{$\operatorname{Grp}_{3}$} & Object Status & \multirow{10}{*}{$\mathrm{B}^{\prime}$} & 1 \\
\hline 16. & & & $\begin{array}{l}\text { Construction } \\
\text { contract }\end{array}$ & & 1 \\
\hline 17. & & & $\begin{array}{c}\text { Advance under } \\
\text { construction } \\
\text { contract / Monthly } \\
\text { payment }\end{array}$ & & 1 \\
\hline 18. & & & $\begin{array}{l}\text { Initial data } \\
\text { (issuance of } \\
\text { working } \\
\text { documentation for } \\
\text { production in the } \\
\text { prescribed manner; } \\
\text { geodetic alignment } \\
\text { base, etc.) }\end{array}$ & & 2 \\
\hline 19. & & & $\begin{array}{c}\text { Transfer of the } \\
\text { construction site } \\
\text { according to the act }\end{array}$ & & 1 \\
\hline 20. & & & $\begin{array}{c}\text { Preparatory work } \\
\text { (arrangement of } \\
\text { domestic premises } \\
\text { and } \\
\text { workplaces, procur } \\
\text { ement processes) }\end{array}$ & & 1 \\
\hline 21. & & & $\begin{array}{l}\text { Opening of the } \\
\text { front of works for } \\
\text { the execution of } \\
\text { monolithic works }\end{array}$ & & 5 \\
\hline 22. & & & Source of financing & & 1 \\
\hline 23. & & & $\begin{array}{l}\text { Additional custom } \\
\text { criterion }\end{array}$ & & 1 \\
\hline 24. & & & Other (optional) & & 1 \\
\hline
\end{tabular}

The determination of the integral type of criticality of the object of the production program of the construction organization is carried out by summing the coefficients in front of the letters in the top-down direction. An example of determining the type of criticality of an object in a real production situation can be presented as follows. The planning department of a construction company 10 March 2020 took information from the management: in the production program it is necessary to include a new object with small volumes of construction and installation work on the load-bearing monolithic structures. The work contract (contract) with the private Customer was promptly signed after the negotiations, advance payment was made in the amount of $30 \%$ of the contract amount for the deployment of the material and technical base at the facility. Terms of work in accordance with the terms of the contract - from March 20, 2020 according to November 
20,2020, the process of transferring working documentation and other initial data (geodetic alignment base, etc.) to ensure the production process has been launched. The act of transfer of the site is signed. However, it was established when visiting the site, which by 20.03. 2020 excavation work on excavation of the pit soil has not yet been completed, and the front of monolithic work on the construction of a foundation slab has not yet been opened. Additional instructions regarding the urgency of the individual stages of work and the specifics of its relationship with the customer were not provided by the project manager.

Together with the project planning department head (manager) forms below following morphological matrix (See Tables 5 and 6).

Table 5. An example of working with a morphological matrix in determining the type of criticality of an object.

\begin{tabular}{|c|c|c|c|c|c|c|}
\hline \multirow[b]{2}{*}{ № } & \multirow{2}{*}{\multicolumn{2}{|c|}{$\begin{array}{c}\text { Morphological feature of } \\
\text { the object of the } \\
\text { production program } \\
\end{array}$}} & Value A & Value B & Value $\mathbf{C}$ & Value D \\
\hline & & & \multicolumn{2}{|c|}{ Value A, } & \multicolumn{2}{|c|}{ Value B' } \\
\hline 1. & \multicolumn{2}{|c|}{$\begin{array}{l}\text { Type of facility in } \\
\text { accordance with the } \\
\text { schedule of work (work } \\
\text { plan) from the production } \\
\text { program }\end{array}$} & $\begin{array}{r}\text { Short } \\
\text { launcher }\end{array}$ & $\begin{array}{r}\text { Long } \\
\text { launcher }\end{array}$ & $\begin{array}{l}\text { Landin } \\
\text { g Object }\end{array}$ & $\begin{array}{l}\text { Transitional } \\
\text { (through) }\end{array}$ \\
\hline 2. & \multicolumn{2}{|c|}{ Object Status } & \multicolumn{2}{|c|}{ Signing a construction contract } & \multicolumn{2}{|c|}{$\begin{array}{l}\text { Participation in the tender } \\
\text { (competition) / Negotiations }\end{array}$} \\
\hline 3. & \multicolumn{2}{|c|}{ Construction contract } & \multicolumn{2}{|c|}{ The contract is signed } & \multicolumn{2}{|c|}{ Contract not signed } \\
\hline 4. & \multicolumn{2}{|c|}{$\begin{array}{l}\text { Advance under construction } \\
\text { contract / Monthly payment }\end{array}$} & \multicolumn{2}{|c|}{ Payment completed } & \multicolumn{2}{|c|}{ Payment failed } \\
\hline 5. & \multicolumn{2}{|c|}{$\begin{array}{l}\text { Initial data (issuance of } \\
\text { working documentation for } \\
\text { production in the prescribed } \\
\text { manner; geodetic alignment } \\
\text { base, etc.) }\end{array}$} & \multicolumn{2}{|c|}{$\begin{array}{c}\text { Front of work is provided with } \\
\text { documentation }\end{array}$} & \multicolumn{2}{|c|}{$\begin{array}{c}\text { Work front not supported by } \\
\text { documentation }\end{array}$} \\
\hline 6. & \multicolumn{2}{|c|}{$\begin{array}{l}\text { Transfer of the construction } \\
\text { site according to the act }\end{array}$} & \multicolumn{2}{|c|}{ Site transferred } & \multicolumn{2}{|c|}{ Site not transferred } \\
\hline 7. & \multicolumn{2}{|c|}{$\begin{array}{c}\text { Preparatory work } \\
\text { (arrangement of domestic } \\
\text { premises and } \\
\text { workplaces, procurement } \\
\text { processes) }\end{array}$} & \multicolumn{2}{|c|}{ Preparatory work completed } & \multicolumn{2}{|c|}{$\begin{array}{l}\text { Preparatory work not } \\
\text { completed }\end{array}$} \\
\hline 8. & \multicolumn{2}{|c|}{$\begin{array}{l}\text { Opening of the front of } \\
\text { works for the execution of } \\
\text { monolithic works }\end{array}$} & \multicolumn{2}{|c|}{ Front of work is open } & \multicolumn{2}{|c|}{ Work front closed } \\
\hline 9. & \multicolumn{2}{|c|}{ Source of financing } & \multicolumn{2}{|c|}{ Budget item } & \multicolumn{2}{|c|}{$\begin{array}{l}\text { Commercial property } \\
\text { (private) }\end{array}$} \\
\hline 10. & \multicolumn{2}{|c|}{ Additional custom criterion } & \multicolumn{2}{|c|}{ Critical } & \multicolumn{2}{|c|}{ Not critical } \\
\hline \multicolumn{7}{|l|}{11.} \\
\hline & \multicolumn{2}{|c|}{$\begin{array}{c}\mathrm{A} \\
\mathrm{A}^{\prime} \geq \mathrm{B}^{\prime}\end{array}$} & $\begin{array}{l}\text { Critical } \\
\text { object of } \\
\text { the 1st kind }\end{array}$ & & & \\
\hline & $\stackrel{\mathrm{B}}{\mathrm{A}^{\prime} \geq \mathrm{B}^{\prime}}$ & $\begin{array}{c}\mathrm{A} \\
\mathrm{B}^{\prime} \geq \mathrm{A}^{\prime}\end{array}$ & & $\begin{array}{l}\text { Critical } \\
\text { sites of } \\
\text { the 2nd kind }\end{array}$ & & \\
\hline & Regardles & $\mathrm{A}^{\prime}$ and $\mathrm{B}^{\prime}$ & & & Non- & tical object \\
\hline
\end{tabular}


Table 6. The integral statement of the coefficients in front of the corresponding letters in determining the type of criticality of objects.

\begin{tabular}{|l|c|c|}
\hline № & Litera & The sum of the coefficients \\
\hline 1. & A & 1 \\
\hline 2. & B & 0 \\
\hline 3. & C & 0 \\
\hline 4. & D & 0 \\
\hline 5. & A $^{\prime}$ & 6 \\
\hline 6. & B $^{\prime}$ & 8 \\
\hline
\end{tabular}

The calculation of the letter coefficients is carried out according to the following formula on an accrual basis ( formula 1 ) : in accordance with the terms of the work, the object is a short start-up ( 1 A component ), the construction company won the tender ( $1 \mathrm{~A}^{\prime}$ component ), the contract is signed and the advance payment is paid $\left(1 \mathrm{~A}{ }^{\prime}+1 \mathrm{~A}^{\prime}\right)$, working documents issued in the production of works in the established order and the construction site itself is transferred to the act $\left(2 \mathrm{~A}^{\prime}+1 \mathrm{~A}^{\prime}\right)$, but the work has not yet been stationed at the facility, not arranged the temporary infrastructure and your Household e premises, work front device under monolithic structures is currently not opened ( $1 \mathrm{~B}^{\prime}+5$ $\left.\mathrm{B}^{\prime}\right)$, and the specific requirements of the object of urgency is not specified $\left(1 \mathrm{~B}^{\prime}+1 \mathrm{~B}^{\prime}\right)$. The new object is a critical object of the second kind, since a short launch object has a greater criticality component $B^{\prime}$ than $A^{\prime}$.

$$
\begin{gathered}
1 A+1 A^{\prime}+1 A^{\prime}+1 A^{\prime}+2 A^{\prime}+1 A^{\prime}+1 B^{\prime}+5 B^{\prime}+1 B^{\prime}+1 B^{\prime} \\
=A+6 A^{\prime}+8 B^{\prime}
\end{gathered}
$$

Assigning a particular degree of criticality for a particular object allows the planning department to distribute the labor resource in accordance with the selected priority (see table 7).

Table 7. The priority of resource allocation depending on the degree of criticality of the object of the

\begin{tabular}{|c|c|c|c|}
\hline № & $\begin{array}{l}\text { The integral genus of } \\
\text { criticality of an object }\end{array}$ & $\begin{array}{l}\text { Description of the } \\
\text { practical situation }\end{array}$ & Resource Allocation Priority \\
\hline 1. & $\begin{array}{l}\text { Critical object of the first } \\
\text { kind }\end{array}$ & $\begin{array}{l}\text { The object must be } \\
\text { delivered in the } \\
\text { current reporting } \\
\text { period. } \\
\text { All conditions for the } \\
\text { implementation of } \\
\text { construction and } \\
\text { installation works are } \\
\text { fulfilled. } \\
\text { Special control over } \\
\text { the saturation of the } \\
\text { front of work with a } \\
\text { labor resource is } \\
\text { required. }\end{array}$ & $\begin{array}{l}\text { - The highest priority of } \\
\text { the distribution of labor } \\
\text { resources }\end{array}$ \\
\hline 2. & Critical Object II & $\begin{array}{l}\text { The object must be } \\
\text { delivered in the } \\
\text { current reporting } \\
\text { period. } \\
\text { Not all conditions for } \\
\text { the implementation } \\
\text { of construction and }\end{array}$ & $\begin{array}{l}\text { High priority distribution } \\
\text { of labor resources . } \\
\text { It is possible to take into } \\
\text { account delays in opening } \\
\text { the front of work to delay } \\
\text { the provision of an object } \\
\text { with a scarce labor }\end{array}$ \\
\hline
\end{tabular}
production program. 


\begin{tabular}{|c|c|c|c|}
\hline № & $\begin{array}{l}\text { The integral genus of } \\
\text { criticality of an object }\end{array}$ & $\begin{array}{l}\text { Description of the } \\
\text { practical situation } \\
\text { installation works are } \\
\text { fully implemented. }\end{array}$ & Resource Allocation Priority \\
\hline 3. & Non-critical object & $\begin{array}{l}\text { The object must be } \\
\text { delivered in the } \\
\text { subsequent reporting } \\
\text { period. }\end{array}$ & $\begin{array}{l}\text { The distribution of labor } \\
\text { by residual } \\
\text { The labor resource is sent } \\
\text { to the object in order to } \\
\text { perform preparatory work } \\
\text { (if necessary) }\end{array}$ \\
\hline
\end{tabular}

\section{Results and Discussion}

The basic algorithm of the implemented software is shown in Figure 3.

Advantages of implementing the algorithm:

1. In the process of implementing the algorithm, means of "conscious" sorting are used, which simplifies the work of the operator (executor in the system of current, strategic and operational planning) in comparison with the classical method of brainstorming in the event of a corresponding critical situation or an ordinary need to relocate labor resources between objects. Approach will move away from the natural and unreasonable choice of administrative decisions under the influence of a particular situation and the human factor to the system an optimization unit with direct participation $\mathrm{m}$ the person (operator) at certain stages of the algorithm.

2. As a result, algorithm is forming array end solutions with a given set of technical and economic indicators as a support element of the system of decision making for the operator - Decision How it works Support the System, the DSS. The most rational solution is chosen by the operator depending on a combination of factors and conditions that are of predominant importance for a specific time period in a particular construction organization. 3. The algorithm is conveniently used precisely for a set of objects, this determines the relevance of its implementation in optimization models when planning production programs of construction organizations containing several objects distributed on a time scale. 


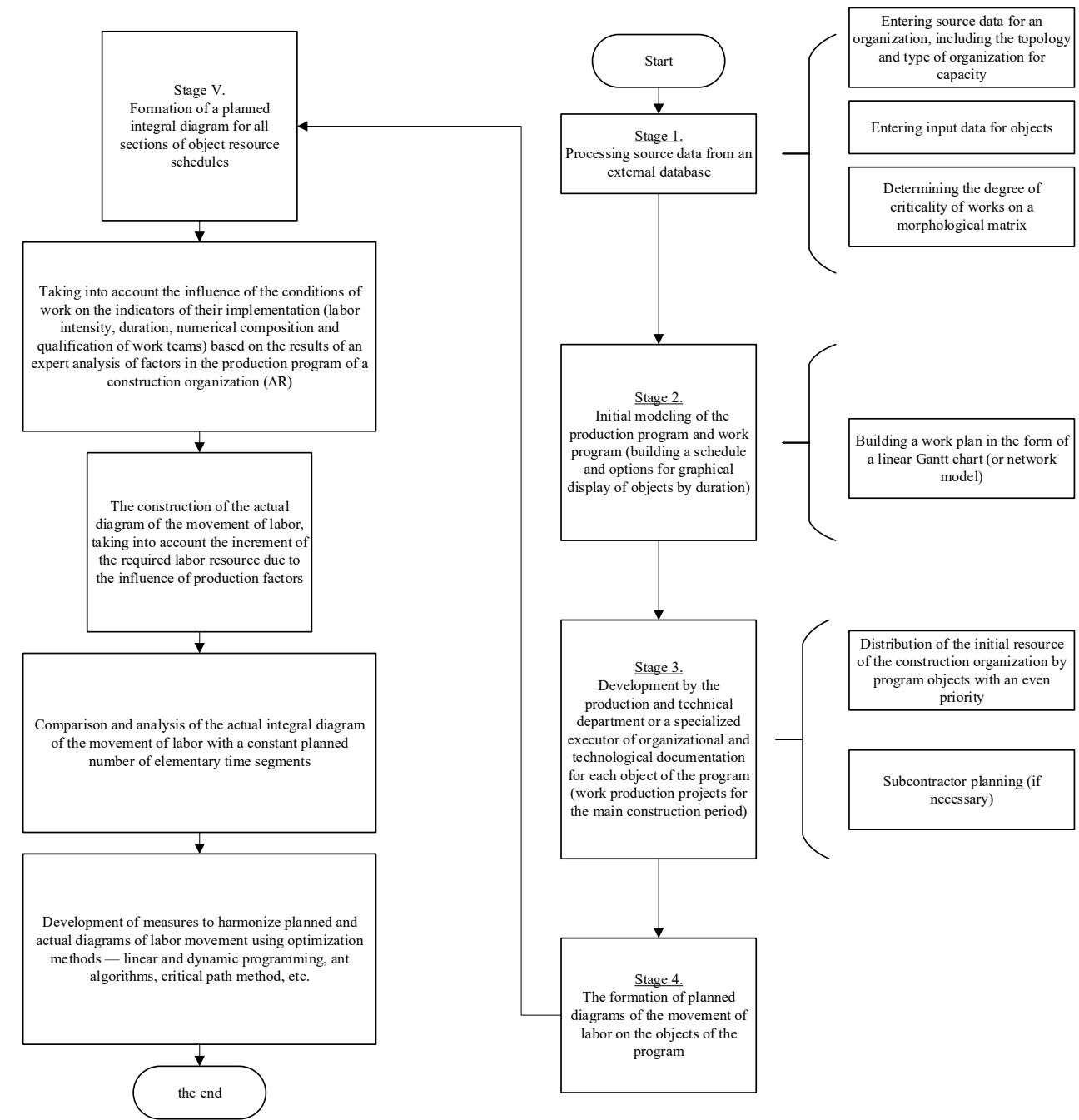

Fig. 3. Software algorithm.

\section{References}

1. J. McConnell, Fundamentals of modern algorithms (Technosphere, Moscow, 2004)

2. Yu.A. Kochetov, A.A. Stolyar, Diskretn. analysis and research. Oper. 12(1), 12-36 (2005)

3. A. Mottaeva, N. Gritsuk, MATEC Web of Conferences 106, 08083 (2017) DOI: 10.1051/matecconf/201710608083

4. M. Dorigo, T. Stutzle, Handbook of Metaheuristics (2003)

5. M. Dorigo, V. Maniezzo, A. Colorni, IEEE Transactions on Systems, Man, and Cybernetics Part B 26(1), 1-13 (1996)

6. S.D. Shtovba, Ant Algorithms, Exponenta Pro. Mathematics in Applications 4, 70-75 (2003) 
7. P. Oleinik, A. Yurgaytis, MATEC Web of Conferences 117, 00130 (2017) https://doi.org/10.1051/matecconf/201711700130

8. D. Topchiy, A. Shatrova, A. Yurgaytis, MATEC Web of Conferences 193, 05032 (2018) https://doi.org/10.1051/matecconf/201819305032

9. P. Oleinik, A. Yurgaytis, MATEC Web of Conferences 193, 05010 (2018) https://doi.org/10.1051/matecconf/201819305010

10. M. Rogalska, W. Bozejko, Z. Hejducki, Automation in Construction 18, 24-31 (2008) doi:10.1016/j.autcon.2008.04.002

11. W. Bozejko, Z. Hejducki, M. Uchroński, M. Wodecki, Journal of Civil Engineering and Management 20 (2014) DOI: 10.3846/13923730.2014.906496 